\title{
KONSEP PENDIDIKAN ISLAM MENURUT IBNU KHALDUN DAN RELEVANSINYA TERHADAP PELAKSANAAN PENDIDIKAN ISLAM DI INDONESIA
}

\author{
Maisaroh \\ Pascasarjana Program Magister Institut Agama Islam Negeri Padangsidimpuan \\ Jalan T. Rizal Nurdin KM. 4,5 Sihitang Padangsidimpuan \\ E-mail: maisaroh@yahoo.co.id
}

\begin{abstract}
Abstrak
Ibnu Khaldun adalah seorang yang selalu tidak puas dengan ilmu yang diperoleh, sehingga ia belajar dari banyak guru. la termasuk orang yang tidak hanya pandai dalam Imu Islam, tetapi juga dalam ilmu umum, seperti sejarah, ekonomi, sosiologi, antropologi dan lain-lain. la juga terkenal dengan pendidik. Dia mengembangkan dan membangun teori tentang pedagogik yang ia tuangkan dalam bukunya yang terkenal Muqoddimah. Dari beberapa metode yang dikemukakan oleh Ibnu Khaldun, ada metode yang relevan dengan pelaksanaan pendidikan Islam di Indonesia. Metode hafalan masih digunakan untuk menghapal mufradat bahasa Arab, qawaid, dan ayat-ayat Al-Qur'an. Dialog biasanya digunakan ketika adanya muzakaroh atau dalam membahas setiap ilmu yang sifatnya membutuhkan diskusi. Widya wisata juga dilakukan oleh peserta didik, terutama kaum santri yang mondok dipesantren selama beberapa tahun.
\end{abstract}

\begin{abstract}
Ibn Khaldun is the one who always dissatisfied with the knowledge obtained, so that he learns from many teachers. It includes people who are not only good at LMU Islam, but also in the general sciences, such as history, economics, sociology, anthropology and others. He is also famous for educators. He developed and developing theories about pedagogical he poured in his famous book Muqoddimah. Of the several methods proposed by Ibn Khaldun, there are methods that are relevant to the implementation of Islamic education in Indonesia. Rote methods are still used to memorize mufradat Arabic, qawaid, and the verses of the Qur'an. Dialogue is usually used when the muzakaroh or in discussing any science that are in need of discussion. Widya tours are also conducted by the students, especially the students who boarded dipesantren for several years.
\end{abstract}

Kata Kunci: Pendidikan, Islam, Ibn Khaldun, dan Indonesia Pendahuluan 
Dewasa ini, dunia Barat mendapat pengakuan dari banyak pihak sebagai bangsa yang lebih maju dan lebih berperadaban. Kemajuan tersebut tidak lepas dari pengembangan ilmu pengetahuan dan teknologi yang begitu pesat. Barat dianggap lebih mampu menyajikan berbagai temuan baru secara dinamis dan varian, sehingga memberikan kontribusi yang besar terhadap sains dan teknologi modern. Oleh karenanya, berbagai belahan dunia merasa tertarik terhadap Barat dan berkiblat kepadanya dalam segala hal, terutama dalam pengembangan ilmu pengetahuan.

Kemajuan ilmu pengetahuan tentunya tidak terlepas dari kualitas pendidikan, sebab ilmu pengetahuan merupakan kajian utama dari pendidikan. Artinya, ketika ilmu pengetahuan berkembang pesat, sudah dipastikan bahwa pendidikan yang dikembangkan jelas berkualitas. Dengan demikian, dalam pemahaman dan penerapan teori-teori pendidikan, para sarjana Barat pun kerap dijadikan sebagai referensi oleh para pemikir dan pelaksana pendidikan.

Fenomena semacam ini juga terjadi dikalangan pemikir dan pelaksana pendidikan di Indonesia. Apalagi ketika disadari bahwa perkembangan pendidikan di Barat lebih maju dari pada pendidikan Islam, khususnya di Indonesia. Melihat kondisi ini maka dengan sendirinya pendidikan nasional melakukan berbagai pembenahan. Salah satu upaya untuk membenahi sistem pendidikan nasional tersebut ialah dengan belajar kepada negaranegara yang lebih maju, terutama dari dunia Barat. Hal ini juga berimplikasi terhadap pengembangan pendidikan Islam. pendidikan Islam yang diakui debagai sub sistem dari sistem pendidikan nasional, turut melakukan berbagai perubahan, termasuk dengan cara menyesuaikan diri dengan pengembanngan di dunai Barat yang dianggap lebih maju tersebut. ${ }^{1}$

Islam memang tidak melarang umatnya untuk belajar dari kalangan non muslim. Umat Islam selalu manampilkan sifat inklusif dalam bergaul dengan orang-orang yang ada disekitarnya, termasuk ketika bersentuhan dengan kebudayaan dan pengetahuan dari kalangan non muslim. Bahkan di

${ }^{1}$ Muhammad Kosim, Pemikiran Pendidikan Islam Ibnu Khaldun (Jakarta: Rineka Cipta, 2012), hlm. 142-143. 1-3. 
era awal, umat Islam banyak belajar dari para ilmuan Yunani yang lebih dahulu memperoleh kemajuan dan bidang pengetahuan, terutama dibidang filsafat. Selanjutnya, ketika umat Islam berkuasa di Barat dan sekitarnya, mereka telah memperlihatkan sikap inklusivitasnya terhadap kebudayaan lokal, takkala orang-orang Barat tidak toleran terhadap kebudayaan lokal.

Sebagaimana yang banyak dibicarakan dalam sejarah bahwa sebelum Barat maju dan berkembang seperti saat ini, umat Islam telah lebih dahulu maju dan berkembang sehingga memilki peradaban yang tinggi. Bahkan, Barat sendiri belajar dari umat Islam, termasuk dalam teori-teori pendidikan. Jika umat Islam pernah diakui sebagai bangsa yang memilki peradaban yang tinggi dari pada bangsa yang lain, sudah barang tentu masa itu telah melahirkan banyak tokoh atau pemikir termasuk dalam pendidikan Islam. bahkan teori-teori Barat yang berkembang dewasa ini pun tidak terturup kemungkinan bersumber dari apa yang telah dihasilkan oleh sarjana muslim. ${ }^{2}$

Oleh karenanya pendidikan Islam memiliki karakteristik tersendiri dan memliki konsep yang ideal jika dibandingkan dengan konsep pendidikan non- Islam. Sebab, prinsip dan dasar dari pendidikan Islam adalah al-qur'an yang memilki kebenaran mutlak. Selanjutnya, dari konsep dasar tersebut, oleh para intelektual Islam telah dikembangkan sehingga melahirkan berbagai konsep dan pemikiran tentang pendidikan Islam, baik secara teoritis maupun praktis. Untuk itu, umat Islam dari generasi ke generasi perlu melakukan kajian terhadap pemikiran yang dilahirkan para intelektual muslim terdahulu dengan harapan, pemikiran tersebut dapat menjadi inspirasi atau referensi untuk mengembangkan dalam meningkatkan pelaksanaan pendidikan Islam yang sesuai dengan konteks kekinian. ${ }^{3}$

Untuk itu, perlu dilakukan kajian ulang terhadap pemikiran para tokoh Islam, terutama yang berpengaruh pada zamannya. Kemudian menganalisis di antara pemikirannya yang relevan untuk dikembangkan dan diterapkan dalam pelaksanaan pendidikan Islam dewasa ini, khususnya pendidikan Islam di Indonesia. Salah satu pemikiran pendidikan Islam yang layak

\footnotetext{
2 bid.

${ }^{3}$ /bid.
} 
mendapat tempat untuk terus dikaji dan dikembangkan adalah pemikiran dari Abdurrhman Ibnu Khaldun atau yang lebih dikenal dengan nama Ibnu Khaldun. ${ }^{4}$

\section{Biorgrafi lbu Khaldun}

Nama lengkap Ibnu Khaldun adalah Abdurrahman bin Muhammad bin Muhammad bin Muhammad bin Hasan bin Jabir bin Muhammad bin Ibrahim bin Abdurrahman bin Ibn Khaldun. Lahir di Tunisia pada 1 Ramadhan 732 H / 27 Mei 1332. Abdurahman nama panggilan waktu kecilnya, nama panggilan keluarganya adalah abu Zaid yang diambil dari nama puteranya yang sulung yaitu Zaid. Menurut Warul Walidin dalam bukunya Konstlasi Pemikiran Paedagogik Ibnu Khaldun Perspektif Pendidikan Modern,lbnu Khaldun mempunyai gelar/laqob yang sering dipanggil orang adalah dengan gelar Waliuddin, gelar ini dia peroleh ketika dia memangku jabatan hakim di Mesir. ${ }^{5}$

Ibnu Khaldun berasal dari keluarga intelektual, yang sedikit tertarik dengan persoalan politik. la biasa berjumpa dengan tokoh intelektual dari Afrika Utara dan Spanyol yang sebagian besar adalah pengungsi dari kekhalifahan timur. Pendidikannya dilalui di Tunisia dan Fez (Maroko) dengan mempelajari berbagai ilmu: menghafal Alqur'an, mempelajari tata bahasa, hukum Islam, hadis, retorika, fiologi dan puisi. Selain itu, ia mempelajari sastra Arab, filsafat, matematika dan astronomi. Kariernya di bidang politik membawanya keluar masuk istana, baik berbagai pemenang maupun pecundang. Pada umur 19 tahun, ia mulai mengabdi pada Ibn Tafrakin, penguasa Tunisia. Selanjutnya pada tahun 1362 Ibn Khaldun menyeberang ke Spanyol dan bekerja pada raja Granada. Di Granada ia menjadi utusan raja untuk berunding dengan Pedro, raja Granada, raja Castila, sedangkan di Sevilla, karena kecakapannya yang luar biasa, ia ditawari bekerja oleh penguasa Kristen itu. ${ }^{6}$

4 lbid.

${ }^{5}$ RA Gunadi, Dari Penekluk Jerussalem Hingga Angka Nol (Jakarta: Republika, 2002), hlm. 119.

6/bid, hlm. 120. 
Catatan historis mengungkapkan suatu hal yang menjadi ciri khas dan melatar belakangi kehidupan Ibnu Khaldun adalah bahwa ia berasal dari keluarga ilmuan yang terhormat dan telah berhasil menghimpun antara jabatan ilmiah dan pemerintahan. Suatu jabatan yang jarang dijumpai dan mampu diraih oleh orang pada masa itu. ${ }^{7}$ Keberadaan keluarganya adalah keturunan Arab yang semula berasal dari Hadramaut, Yaman Selatan setelah pidah ke Hijaz, diantara nenek moyang Ibnu Khaldun ada yang turut dalam barisan pejuang muslim menaklukan Andalusia. Karena mereka orang yang mencapai Andalusia pada gelombang-gelombang awal, keluarga Khaldun nampaknya cukup berhasil dan tumbuh menjadi salah satu keluarga aristorkrat di kota Selvia.

Disebabkan kekacauan faktor sosial yang merbak diseluruh Andalusia sebelum berakhirnya kekuasaan dinasti-dinasti Islam mendorong keluarga Khaldun meninggalkan selvia menjelang terjadinya peristiwa reconquista. Merekapun selamat dari huru-hara berdarah itu. Keluarga Khaldun pindah menyeberangi Selat Gibraltar dan mendarat di Afrika Utara untuk kemudian menetap di Tunasia yang kala ini ada dibawah kekuasaan Abu Zakarya dari dinasti inilah Ibnu Khaldun dilahirkan. ${ }^{8}$

Perjalanan hidupnya penuh dengan kegiatan ilmiah dan peristiwa sosial politik yang sangat intens sehingga menempatkan dirinya sebagai ulama, filosof dan ilmuan yang dikagumi. Jadi ia bukan seorang ilmuan yang memilih hidup dimana gading terenalisasi dari umatnya, seperti hal kebanyakan ulama klasik Islam, ia berhasil memadukan intensitas kerja ilmiah dengan partisipasi aktif sebagai anggota masyarakatnya. Pendidikan yang diperolehnya cukup mendukung bagi kesuksesan karirnya. ${ }^{9}$

Dan pada tahun 1382 ia pergi ke Iskandariah. Tetapi dalam perjalanan hajinya ia singgah di Mesir. Raja dan rakyat Mesir yang cukup mengenal reputasi Khaldun telah menyebabkan ia tidak melanjutkan

${ }^{7}$ Ramayulis, Ensiklopedi Tokoh pendidikan Islam (Jakara: Quantum Teaching, 2005), hlm. 17.

${ }^{8}$ Fakhur Ray Dalimunthe, Filsafat Pendidikan Islam (Medan: IAIN Perss, 2002), hlm. 152.

${ }^{9} /$ bid, hlm. 153. 
perjalanan hajinya. Di Daerah ini ia ditawari jabatan guru kemudian ketua mahkamah agung dibawah pemerintahan dinasti Mamluk. ${ }^{10}$ Dengan jabatannya yang terakhir, ia bukan saja mengalami masalah yang sama seperti yang dihadapi di Granada dan Aljazair, tetapi juga telah menyebabkan ia kehilangan keluarga dan harta bendanya. Ibnu Khaldun dan beberapa orang terkemuka lainnya tetap tidak pulang. la diserahi tugas berunding mengenai penyerahan kota itu ke tangan Timur Lenk. Di tangan Timur Lenk, Damaskus dihancurkan. Tetapi Khaldun berhasil menyelamatkan bukan hanya dirinya, melainkan juga beberapa orang terkemuka, anggota tim terunding ke Mesir.

Pada suatu riwayat sebagaimana yang dituliskan dalam Ensiklopedi Islam, perjalanan hidup Ibnu Khaldun penuh dengan kecemerlangan ia pernah berjumpa dengan penakluk Mongol (Timur Lank) pada tahun $1401 \mathrm{M}$ diluar perbatasan Damaskus. Penakluk Mongol tersebut menyambut dan menawarkan ilmuan ini sebagai pejabat pemerintahan. Akan tetapi tidak tahu alasan jelas Ibnu Khaldun memilih kembali ke Kairo dan melanjutkan pekerjaannya sebagai Waliullah (Qadhi), akhirnya di sinilah la menghabiskan sisa umurnya sampai dipanggil oleh Allah kehadirat-Nya, pada tahun 1406 dalam usia 74 tahun, bersama jabatan yang dipegangnya. ${ }^{11}$

Karya-karya yang ditinggalkan Ibnu Khaldun yang terkenal sebagai ilmuwan besar adalah karyanya "Muqaddimah". Rasanya memang aneh ia terkenal justru karena muqaddimahnya bukan karena karyanya yang pokok (al-'Ibar), namun pengantar al-'Ibarnyalah yang telah membuat namanya diagung-agungkan dalam sejarah intelektualisme. Karya monumentalnya itu telah membuat para sarjana baik di Barat maupun di Timur begitu mengaguminya. Sampai-sampai Windellband dalam filsafat sejarahnya menyebutnya sebagai "Tokoh ajaib yang sama sekali lepas, baik dari masa lampau maupun masa yang akan datang".12

\footnotetext{
${ }^{10}$ RA Gunadi, Op, cit, hlm. 120.

${ }^{11}$ Huseiyn Ahmad Amin, Seratus Tokoh Dalah Sejarah Islam (Bandung: Maktabah Madbuli, Kairo, Mesir. 2003), hlm. 242.

12 Jamil Ahma, Seratus Muslim Terkemuka (Jakarta: Pustaka firdaus, 1993), hlm. 421.
} 
Berikut akan disebutkan hasil karya-karya Ibnu Khaldun yang terkenal:

1. Kitab Muqaddimah, yang merupakan buku pertama dari kitab al-'Ibar, yang terdiri dari bagian muqaddimah (pengantar). Buku pengantar yang panjang inilah yang merupakan inti dari seluruh persoalan, dan buku tersebut pulalah yang mengangkat nama Ibnu Khaldun menjadi begitu harum. Adapun tema muqaddimah ini adalah gejala-gejala sosial dan sejarahnya. ${ }^{13}$ Mukoddimah itu membuka jalan menuju pembahasan ilmu-ilmu sosial, oleh karena itu, dalam sejarah. Ibnu Khaldun dipandang sebagai peletak ilmu-ilmu sosial dan politik Islam. Menurut pandangannya politik tidak dapat dipisahkan dari kebudayaan, dan masyarakat di bedakan antara masyarakat kota dan desa. Studi Islam menurut pandangnya terdidri dari ulum tabi'iyyah dan naqliyyah. ${ }^{14}$

2. Kitab al-'Ibar, wa Diwan al-Mubtada' wa al-Khabar, fi Ayyam al-'Arab wa al-'Ajam wa al-Barbar, wa man Asharuhum min dzawi as-Sulthani al'Akbar. (Kitab Pelajaran dan Arsip Sejarah Zaman Permulaan dan Zaman Akhir yang mencakup Peristiwa Politik Mengenai Orang-orang Arab, Non-Arab, dan Barbar, serta Raja-raja Besar yang Semasa dengan Mereka), yang kemudian terkenal dengan kitab 'Ibar, yang terdiri dari tiga buku: Buku pertama, adalah sebagai kitab Muqaddimah, atau jilid pertama yang berisi tentang: Masyarakat.

3. Kitab al-Ta'rif bi Ibnu Khaldun wa Rihlatuhu Syarqon wa Ghorban atau disebut al-Ta'rif, dan oleh orang-orang Barat disebut dengan Autobiografi, merupakan bagian terakhir dari kitab al-'lbar yang berisi tentang beberapa bab mengenai kehidupan Ibnu Khaldun. Dia menulis autobiografinya secara sistematis dengan menggunakan metode ilmiah, karena terpisah dalam bab-bab, tapi saling berhubungan antara satu dengan yang lain. ${ }^{15}$

${ }^{13}$ RA Gunadi, Op cit, hlm. 122.

${ }^{14}$ Dewan Redaksi Ensiklopedi Islam, Ensiklopedi Islam (Jakarta: Ichtiar Van Hoeve, 1994), hlm. 158-159.

15 Jamil Ahmad, Op. cit., hlm. 422-423. 


\section{Pandangan Ibnu Khaldun Tentang Pendidikan Islam}

1. Tujuan Pendidikan

Menurut Ibnu Khaldun ada tiga tingkatan tujuan yang hendak dicapai dalam proses pendidikan, yaitu:

a. Pengembangan malakah dalam bidang tertentu

Kata malakah mengandung makna "Menjadikan sesuatu dimiliki atau dikuasai, suatu sifat yang mengakar pada jiwa". Ibnu khaldun mendefenisikan malakah yaitu, sifat yang berurat berakar, sebagai hasil belajar atau mengerjakan sesuatu berulang kali, sehingga hasil pekerjan itu dengan kokoh tertanam dalam jiwa. Malakah dalam proses belajar adalah suatu tingkat pencapaian (achievement) dari penguasaan materi keilmuan, ketrampilan dan sikap tertentu akibat dari suatu proses belajar secara intens, bersungguh-sungguh dan sistematis. ${ }^{16}$

Ibnu Khaldun menggunakan kata malakah dalam arti mahara (kemahiran), yakni kemahiran seseorang dalam bidang tertentu sebagai tujuan pendidikan. Malakah diperoleh melalui latihan, Ibnu Khaldun mencontohkan dengan pentingnya membiasakan diri berbicara dengan jelas dalam perdebatan ilmiah. Pemikiran/pemahaman yang baik harus disertai dengan ekspresi yang benar, jelas dan teratur untuk dapat menjernihkan suatu persoalan. ${ }^{17}$

Karakteristik malakah oleh Al-Din dalam pribadi seseorang sebagai berikit:

1) Malakah dihasilkan dengan kontinuitas praktek.

2) Malakah mengubah keterampilan abstrak menjadi keterampilan yang praktis.

3) Malakah intelektual maupun praktis tidak berkembang tanpa latihan yang lebih sempurna.

16 Waru Walidin, Katalog Dalam Terbitan (KDT) Konstelasi Pemikiran Pedagogik Ibnu Khaldun (Yogyakarta: Nadiya Foundation, 2003), hlm. 114.

${ }^{17}$ Fakhrur Razy Dalimunthe, Op. cit., hlm. 156. 
4) Semakin mantap dasar yang dimiliki seseorang, semakin mantap dan kokoh malakah yang akan dihasilkannya.

5) Ada hubungan erat antara memperoleh malakah dengan penerapan praktisnya dalam mengajar.

Pengembangan kemahiran (al-malakah atau skil) dalam bidang tertentu. Orang awam bisa meneliti, pemahaman yang sama tentang suatu persoalan dengan seorang ilmuwan. Akan tetapi potensi al-malakah tidak bisa demikian oleh setiap orang, kecuali setelah ia benar-benar memahami dan mendalami suatu disiplin tertentu.

b. Penguasaan keterampilan professional sesuai dengan tuntutan zaman (lingkungan dan materi).

Dalam hal ini pendidikan hendaknya ditujukan untuk memperoleh ketrampilan yang tinggi pada potensi tertentu. Pendekatan ini akan menunjang kemajuan dan kontinuitas sebuah kebudayaan, serta peradaban umat manusia di muka bumi. Pendidikan yang meletakkan keterampilan sebagai salah satu tujuan yang hendak dicapai dapat diartikan sebagai upaya mempertahankan dan mengutamakan peradaban secara keseluruhan.

c. Pembinaan pemikiran yang baik.

Kemampuan berpikir merupakan jenis pembeda antara manusia dengan binatang. Oleh karena itu, pendidikan hendaknya di format dan dilaksanakan dengan terlebih dahulu memperhatikan pertumbuhan dan perkembangan potensi-potensi psikologis peserta didik. Melalui pengembangan akal, akan dapat membimbing peserta didik untuk menciptakan hubungan kerjasama sosial dalam kehidupannya, guna mewujudkan kesejahteraan hidup di dunia dan akhirat.

Untuk mencapai tujuan tersebut, maka keberadaan pendidikan merupakan bahagian integral dari konstruksi sebuah peradaban. Proses ini merupakan upaya mulia karena berhubungan dengan penyebaran 
ilmu pengetahuan. Uapaya tersebut merupakan salah satu tugas manusia sebagai khalifah fil al-ardh. ${ }^{18}$

Dengan demikian, tujuan pendidikan Islam menurut Ibnu Khaldun dapat dilihat dari beberapa segi, yaitu: ${ }^{19}$

a. Ibnu khaldun memandang bahwa dari segi struktur kepribadiannya, pendidikan Islam bertujuan untuk mengembangkan potensi jasmani dan rohani (akal, nafs, dan ruh) manusia secara optimal, sehinnga eksistensi kemanusiaanya menjadi sempurna.

b. Ibnu Khaldun juga berpendapat dari segi tabiatnya sebagai mkhluk sosial, pendidikan Islam bertujuan untuk mendidik manusia agar mampu hidup bermasyarakat dengan baik sehingga dengan ilmu dan kemampuan yang dimiliknya, ia mampu membangun masyarakat yang berperadaban maju.

c. Dari segi fungsi dan peranannya sebagai hamba Allah dan Khalifah Fil Ardhi, pendidikan Islam bertujuan untuk mendidik manusia agar mampu melakukan aktivitas yang bernilai ibadah sekaligus mampu mengemban amanah sebagai khalifah dalam memelihara jagad raya ini.

2. Hakikat Pendidik

Untuk mencapai tujuan pendidikan dan pembelajaran, maka keberadaan pendidik merupakan komponen integral dari pendidikan dan pembelajaran. Meskipun tidak memaparkan uraian tentang pendidik atau guru secara spesifik, namun Ibnu Khaldun menyatakan bahwa mengajar adalah suatu profesi, bahkan bagian integral dari industri. Karena suatu profesi, dan profesi adalah pekerjaan yang berkaitan langsung dengan pendapatan, maka guru dibenarkan mendapatkan imbalan, upah atau gaji dari pekerjaan mengajar yang dilakukannya.

18 Al-Rasyidin dan Samsul Nijar, Filsafat Pendidikan Islam (Jakarta: Ciputat Press, 2005), hlm. 94.

${ }^{19}$ Muhammad Kosim, Op.Cit., hlm, 126-127. 
Menurut Ibnu Khaldun, guru adalah suatu profesi yang sangat mulia karena berhubungan langsung dengan penyebaran ilmu pengetahuan dan peningkatan kapasitas berpikir yang akan mengantarkan manusia pada kesempurnaan eksistensialnya. Dalam perjalanan kesejarahan manusia diberbagai belahan dunia, profesi guru ini terus mengalami perkembangan. Ibnu Khaldun mengisyaratkan bahwa seorang pendidik hendaknya memiliki pengetahuan yang memadai tentang perkembangan psikologis peserta didik. ${ }^{20}$

Pengetahuan ini akan sangat membantunya untuk mengenal setiap individu peserta didik dan mempermudah dalam melaksanakan proses belajar mengajar. Para pendidik hendaknya mengetahui kemampuan dan daya serap peserta didik. Kemampuan ini akan bermanfaat bagi menetapkan materi pendidikan yang sesuai dengan tingkat kemampuan peserta didik.

Bila pendidik memaksakan materi di luar kemampuan peserta didiknya, maka akan menyebabkan kelesuan mental dan bahkan kebencian terhadap ilmu pengetahuan yang diajarkan. Bila ini terjadi, maka akan menghambat proses pencapaian tujuan pendidikan. Seorang guru hendaknya menjauhkan penjelasan yang sifatnya umum, dan global. Oleh karena itu, diperlukan keseimbangan antara materi pelajaran yang sulit dan mudah dalam cakupan pendidikan. ${ }^{21}$

Selanjutnya, menurut Ibnu Khaldun seorang pendidik akan berhasil dalam tugasnya apabila memiliku sifat-sifat yang mendukung profesionalismenya. Pertama, pendidik hendaknya lemah lembut, senantiasa menjauhi sifat kasar, dan menjauhi hukuman yang merusak fisik dan psikis peserta didik, apalagi terhadap anak-anak yang masih kecil. Jika tidak, hal ini dapat menimbulkan kebiasaan yang buruk bagi mereka.

Kedua, pendidik hendaknya menjadikan dirinya sebagai uswah alhasanah bagi peserta didik. Keteladanan disini dipandang sebagai suatu

${ }^{20}$ Al-Rasyidin dan Wahyuddin Nur Nasution, Teori Belajar dan Pembelajaran (Medan: Perdana Publishing, 2011), hlm. 90-91.

${ }^{21}$ A. Susanto, Pemikiran Pendidikan lalam (Jakarta: Amzah, 2010), hlm. 47-48. 
cara yang mampu untuk membina akhlak dan menanamkan prinsipprinsip terpuji kepada jiwa peserta didik. Menurut Ibnu Khaldun, peserta didik akan memperoleh ilmu pengatahuan, ide, akhlak, sifat-sifat terpuji, dan pendidikan adakalanya dengan melakukan kontak pribadi dengan lingkungannya khususnya kepribadian para pendidik. ${ }^{22}$

Ketiga, pendidik hendaknya memerhatikan kondisi peserta didik dalam memberikan pengajaran sehinga metode dan materi dapat disesuaikan secara proporsional. Keempat, pendidik hendaknya mengisi waktu luang dengan aktivitas yang berguna. Menurut Ibnu Khaldun, diantara cara yang paling baik untuk mengisi waktu senggang adalah dengan membiasakan anak membaca, terutama membeca al-Qur'an, sejarah, syair-syair, hadis Nabi, bahasa Arab, dan retorika.

Kelima, pendidik harus profesional dan mempunyai wawasan yang luas tentang peserta didik. Terutama yang berkaitan dengan pertumbuhan dan perkembangan jiwa peserta didik. Diantara sikap terpenting yang harus dimiliki seorang pendidik adalah kemampuan mengungkapkan diri dengan kelas dalam dialog dan diskusi, serta mencoba menyampaikan kemampuan ilmiah kepada peserta didik yang dianggap sebagai suatu keahlian dalam pelajaran. ${ }^{23}$

3. Hakikat Peserta Didik

Peserta didik merupakan orang yang belum dewasa dan memiliki sejumlah potensi (kemampuan) dasar yang masih perlu dikembangkan. Di sini peserta didik merupakan makhluk Allah yang memiliki fitrah jasmani maupun rohani yang belum mencapai taraf kematangan baik bentuk, ukuran, maupun perimbangan pada bagian-bagian lainnya. Dari segi rohaniah, ia memiliki bakat, kehendak, perasaan, dan pikiran yang dinamis dan perlu dikembangkan.

Melalui paradigma di atas, peserta didik merupakan subjek dan objek pendidikan yang memerlukan bimbingan orang lain (pendidik)

22 Syamsul Kurniawan dan Erwin Mahrus, Jejak Pemikiran Tokoh Pendidikan Islam (Jakarta: Ar-Ruzz Media, 2011), hlm. 107.

23 lbid, hlm 108. 
Maisaroh

untuk membantu mengarahkannya mengembangkan potensi yang dimilikinya, serta membimbingnya menuju kecerdasan.

Pada dasarnya peserta didik adalah:

a. Peserta didik bukan merupakan miniatur orang dewasa, akan tetapi memiliki dunianya sendiri. Hal ini sangat penting untuk dipahami agar perlakuan terhadap mereka dalam proses kependidikan tidak disamakan dengan pendidikan orang dewasa, bahkan dalam aspek metode, mengajar, materi yang akan diajarkan, sumber bahan yang digunakan dan sebagainya.

b. Peserta didik adalah manusia yang memiliki diferensiasi periodesasi perkembangan dan pertumbuhan. Aktivitas kependidikan Islam disesuaikan dengan tingkat pertumbuhan dan perkembangan yang pada umumnya dilalui oleh setiap peserta didik. Karena kadar kemampuan peserta didik ditentukan oleh faktor-faktor usia dan periode perkembangan atau pertumbuhan potensi yang dimilikinya.

c. Peserta didik adalah manusia yang memiliki kebutuhan, baik menyangkut kebutuhan jasmani maupun kebutuhan rohani yang harus dipenuhi.

d. Peserta didik adalah makhluk Allah yang memiliki perbedaan individual (diferensiasi individual), baik yang disebabkan oleh faktor pembawaan maupun lingkungan di mana ia berada.

e. Peserta didik merupakan resultan dari dua unsur alam, yaitu jasmani dan rohani. Unsur jasmani memiliki daya fisik yang menghendaki latihan dan pembiasaan yang dilakukan melalui proses pendidikan. Sementara unsur rohani memiliki dua daya, yaitu daya akal dan daya rasa. Untuk mempertajam daya akal maka proses pendidikan hendaknya melalui ilmu-ilmu rasional. Adapun untuk mempertajam daya rasa dapat dilakukan melalui pendidikan akhlak dan ibadah. ${ }^{24}$

4. Kurikulum Pendidikan dan Klasifikasi ilmu

Kurikulum merupakan landasan yang digunakan pendidik untuk membimbing peserta didiknya ke arah tujuan pendidikan yang

24 A. Haris Hermawan, Filsafat Pendidikan Islam (Jakarta: Direktorat Jenderal Pendidikan Islam Depertemen Agama Republik Indonesia, 2009), hlm. 324-325. 
diinginkan melalui akumulasi sejumlah pengetahuan, ketrampilan dan sikap mental.

Pemikiran Ibnu Khaldun tentang kurikulum pendidikan dapat dilihat dari konsep epistemologinya. Menurutnya, ilmu pengetahuan dalam kebudayaan umat Islam dapat dibagi kepada dua bagian, yaitu:

a. Ilmu Pengetahuan syar'iyyah (al-ulum al-naqliyah) yang berkenaan dengan hukum dan ajaran agama Islam. Ilmu pengetahuan syar'iyyah yaitu ilmu-ilmu yang bersandar pada "warta" otoritatif syar'i (Tuhan/Rosul) dan akal manusia tidak mempunyai peluang untuk "mengotak-atiknya", kecuali dalam lingkup cabang-cabangnya. Itu pun masih harus berada dalam kerangka diktum dasar "warta" otoritatif tersebut. Ilmu ini diantaranya adalah tentang Al-Qur'an, Hadits, prinsip-prinsip syari'ah, fiqh, teologi, dan sufisme.

b. Ilmu pengetahuan filosofis (ulum al-aqliyah), yaitu ilmu yang bersifat alami yang diperoleh manusia dengan kemampuan akal dan pikirannya. Lingkup persoalan, prinsip-prinsip dasar dan metode pengembangannya sepenuhnya berdasar daya jangkau akal pikir manusia.

Ilmu pengetahuan filosofis meliputi:

1) Ilmu Mantik (logika), yakni ilmu yang menjaga proses penalaran dari hal-hal yang sudah diketahui agar tidak mengalami kesalahan.

2) Ilmu Pengetahuan Alam, yakni ilmu tentang realitas empirisinderawan, baik berupa unsur-unsur atomik, bahan-bahan tambang, benda-benda angkasa maupun gerak alam jiwa manusia yang menimbulkan gerak dan sebagainya.

3) Ilmu Metafisika yakni hasil pemikiran tentang hal-hal metafisis.

4) IImu Matematika, ilmu ini meliputi empat disiplin keilmuan yang disebut al-Ta'lim yakni: a) IImu Ukur (al -Handasah); b) IImu Aritmatika; c) IImu Musik; d) Astronomi. ${ }^{25}$

${ }^{25}$ Ramayulis, Op.cit., hlm.27-28 
Ilmu pengetahuan filosofis juga sering disebut sains alamiah. Hal ini disebabkan karena dengan potensi akalnya, setiap orang memiliki kemampuan untuk menguasainya dengan baik. IImu pengetahuan syar'iyyah dan filosofis merupakan pengetahuan yang ditekuni manusia (peserta didik) dan saling berinteraksi, baik dalam proses memperoleh atau proses mengajarkannya. Konsepsi ini kemudian merupakan pilar dalam merekonstruksi kurikulum pendidikan Islam yang ideal, yaitu kurikulum pendidikan yang mampu mengantarkan peserta didik yang memiliki kemampuan membentuk dan membangun peradaban umat manusia.

\section{Metode Pendidikan}

Metode pendidikan adalah segala segi kegiatan yang terarah yang dikerjakan oleh guru dalam rangka kemestian-kemestian mata pelajaran yang diajarkannya. Ciri-ciri perkembangan peserta didik dan suasana alam di sekitarnya dan tujuan membimbing peserta didik untuk mencapai proses belajar yang diinginkan dan perubahan yang dikehendaki pada tingkah laku mereka.

Metode pendidikan sama halnya dengan metode pembelajaran (pengajaran), yang mana pemikiran Ibnu Khaldun tentang metode pendidikan terungkap lewat empat sikap reaktifnya terhadap gaya para pendidik (guru) dimasanya, yaitu: ${ }^{26}$

a. kebiasaan mendidik dengan metode "indoktrinasi" terhadap anakanak didik, para pendidik memulai dengan masalah-masalah pokok yang ilmiah untuk diajarkan kepada anak-anak didik tanpa mempertimbangkan kesiapan mereka untuk menerima dan menguasainya. Maka Ibnu Khaldun lebih memilih metode secara gradual sedikit demi sedikit, pertama-tama disampaikan permasalahan pokok tiap bab, lalu dijelaskan secara global dengan mempertimbangkan tingkat kecerdasan dan kesiapan anak didik.

b. memilah-milah antara ilmu-ilmu yang mempunyai nilai instrinsik, semisal ilmu-ilmu keagamaan, kealaman, dan ketuhanan, dengan

${ }^{26}$ Abuddin Nata, Filsafat Penididkan Islam (Jakarta: Logos Wacana IImu, 1997), hlm. 177. 
ilmu-ilmu yang instrumental, semisal ilmu-ilmu kebahasa-Araban, dan ilmu hitung yang dibutuhkan oleh ilmu keagamaan, serta logika yang dibutuhkan oleh filsafat. ${ }^{27}$

c. Ibnu Khaldun tidak menyukai metode pendidikan yang terkait dengan strategi berinteraksi dengan anak yang "militeristik" dan keras, anak didik harus seperti ini dan seperti itu, karena berdampak buruk bagi anak didik berupa munculnya kelainan-kelainan psikologis dan perilaku nakal. ${ }^{28}$

Ibnu Khaldun mengajarkan agar pendidik bersikap sopan dan halus pada muridnya. Hal ini termasuk juga sikap orang tua terhadap anaknya, karena orang tua adalah pendidik yang utama. Selanjutnya jika keadaan memaksa harus memukul si anak, maka pemukulan tidak boleh lebih dari tiga kali. ${ }^{29}$

6. Evaluasi Pendidikan

Evaluasi pendidikan Islam dapat dibagi batasan sebagai suatu kegiatan untuk menentukan taraf kemajuan suatu pekerjaan dalam proses pendidikan Islam. Dalam ruang lingkup terbatas, evaluasi dilakukan adalah dalam rangka menjelaskan tingkat keberhasilan pendidik dalam menyampaikan materi pendidikan Islam kepada peserta didik. Sedangkan dalam ruang lingkup luas, evaluasi dilakukan untuk mengetahui tingkat keberhasilan dan kelemahan suatu proses pendidikan Islam (dengan seluruh komponen yang terlibat di dalamnya) dalam mencapai tujuan pendidikan yang dicita-citakan.

Secara umum ada empat kegunaan evaluasi dalam pendidikan Islam, yaitu:

a. Dari segi pendidik, evaluasi berguna untuk membantu seorang pendidik mengetahui sudah sejauh mana hasil yang dicapai dalam pelaksanaan tugasnya.

\footnotetext{
${ }^{27}$ /bid, hlm.178.

${ }^{28} / \mathrm{bid}$, hlm. 178.

${ }^{29}$ A. Susanto, Pemikiran Pendidikan Islam (Jakarta: Amzah, 2010), hlm. 47.
} 
b. Dari segi peserta didik, evaluasi berguna membantu peserta didik untuk dapat mengubah atau mengembangkan tingkah lakunya secara sadar ke arah yang lebih baik.

c. Dari segi ahli fikir pendidikan Islam, evaluasi berguna untuk membantu para pemikir Islam dan membantu mereka dalam merumuskan kembali teori-teori pendidikan Islam yang relevan dengan arus dinamika zaman yang senantiasa berubah.

d. Dari segi politik pengambil kebijakan pendidikan Islam (pemerintah), evaluasi berguna untuk membantu mereka dalam membenahi sistem pengawasan dan mempertimbangkan kebijakan yang akan diterapkan dalam suatu pendidikan nasional (Islam). ${ }^{30}$

Konsep evaluasi dalam pendidikan Islam bersifat menyeluruh, baik dalam hubungan manusia dengan Allah SWT sebagai Pencipta, hubungan manusia dengan manusia lainnya, hubungan manusia dengan alam sekitarnya, dan hubungan manusia dengan dirinya sendiri. Spectrum kajian evaluasi dalam pendidikan Islam tidak hanya terkonsentrasi pada aspek kognitif, tetapi justru dibutuhkan keseimbangan yang terpadu antara penilaian iman, ilmu, dan amal. Sebab kualitas keimanan, keilmuan, dan amal shalihnya. Kesemuanya itu merupakan bahan pemikiran bagi pengembangan sistem evaluasi dalam pendidikan Islam. ${ }^{31}$

\section{Relevansi Pemikiran Ibnu Khaldun Terhadap Pelaksanaan Pendidikan Islam di Indonesia}

Dalam pembahasan ini, akan dibahas beberapa relevansi pemikiran Ibnu Khaldun terhadap pelaksanaan pendidikan Islam di Indonesia, yaitu:

1. Relevansi tujuan pendidikan Islam

Adapun dalam konteks kelndonesiaan, relevansi konsep Ibnu Khaldun yang dijelaskan diatas tampaknya masih bersifat teoritis. Sebab dalam pelaksanaanya, manusia masih dipandang secara parsial.

${ }^{30}$ A. Haris Hermawan, Op., cit, hlm. 274-275.

31 Ibid, hlm. 281. 
Akibatnya, tujuan pendidikan yang telah dirumuskan terhambat dalam pencapaiannya. Hal ini menunujukkan bahwa antara yang ideal tidak sesuai dengan realita. Pelaksanaan pendidikan Islam di Indonesia lebih menitikberatkan kepada aspek kognitif. Padahal aspek kognitif yang merupakan potensi akan hanya merupakan satu bagian dari kepriabadian manusia, akibatnya, pendidikan kurang berhasil melahirkan out come yang berakhlak karimah dan bertanggung jawab sebagaimana yang dicita-citakan dalam tujuan pendidikan Islam. Untuk itu, pendidikan Islam perlu melakukan reorientasi terhadap tujuannya. Disebut reorientasi karena konsep dasar pendidikan Islam tentang tujuannya telah jelas. Dalam hal ini perlu kembali dibangun paradigma holistikintegralistik. Paradigma ini memandang pendidikan sebagai sarana untuk mengembangkan potensi manusia secara utuh.

Manusia dipandang sebagai kesatuan yang bulat, yakni kesatuan jasmani dan rohani, kesatuan makhluk pribadi-makhluk sosial-makhluk Tuhan, kesatuan melangsungkan, mempertentangkan, dan mengembangkan hidupnya. Dengan paradigma ini, maka tujuan pendidikannya akan mengintroduksi terbentuknya manusia seutuhnya dan masyarakat seutuhnya, namun yang terpenting dari semua itu ialah kebijakan pendidikan dan pelaksanaanya mestinya tetap mengacu kepada konsep dasar tentang hakikat manusia tersebut. Disini diperlukannya konsistensi antar teori dengan praktik. ${ }^{32}$

2. Relevansi pendidik dan peserta didik

Meskipun Ibnu Khaldun tidak khusus berbicara tentang pendidik dengan peserta didik, tetapi konsep yang beliau tawarkan tetap relevan untuk dikaji dan dikembangkan dalam meningkatkan pendidikan Islam di Indonesia. Sesuai dengan amanah UU No. 14. Tahun 2005 tentang guru dan dosen, guru dituntut agar memiliki kompetensi profesional, paedagogis, individual dan sosial. Pandangan Ibnu Khaldun tampaknya

32 Ali Maksum dan Luluk Yunan Ruhendi, Paradigma Pendidikan Universal di Era Modern dan Post-Modern (Yogyakarta:IRCiSoD, hlm. 23. 
mampu mengarahkan guru untuk mencapai keempat kompetensi tersebut.

Kemudian, pandangan Ibnu Khaldun tentang profesi guru dan berhak mendapatkan upah yang layak, juga televan dengan kebutuhan guru dewasa ini. Dalam UU No. 14 Tahun 2005 tersebut, telah ditetapkan adanya sertifikasi guru, selain untuk mendorong kompetensi guru, juga bertujuan untuk meningkatkan kesejahteraan guru. Dengan adanya UU ini diharapkan pendidik dapat bekerja secara profesional dan pemikirannya tidak terkuras untuk memenuhi kebutuhan ekonominya.

Adapun peserta didik, diharapkan agar menyadari bahwa ilmu yang dituntut adalah karunia Allah semata, rajin menuntut ilmu, tidak pesimis, dan tidak tergantung pada kekuatan logika. Pandangan seperti ini menunjukkan bahwa peserta didik tidak hanya dituntut cerdas secara intelektual semata, tetapi mesti cerdas secara emosional, spritual, dan terpenting lagi cerdas secara religious sehingga jadilah ia sebagai anak yang saleh. Inilah profil peserta didik yang ideal dan senantiasa diharapkan sebagaimana yang terkandung dalam tujuan pendidikan nasional. ${ }^{33}$

3. Relevansi kurikulum

Klasifikasi ilmu sebagaimana yang telah dirumuskan oleh Ibnu Khaldun juga terjadi dalam pendidikan Islam di Indonesia. Jika Ibnu Khaldun membagi ilmu secara garis besar kedalam dua bentuk, al-ulum al-naqliyah dan al-ulum al-aqliyah, maka di Indonesia juga dibagi dalam dua bentuk, yaitu ilmu agama dan ilmu umum. Kedua bentuk ilmu ini menjadi bagian dalam kurikulum pendidikan Islam di Indonesia.

Dalam pendidikan Islam yang diterapkan di Indonesia, dikenal adanya lima aspek materi pokok pendidikan agama Islam, yaitu:

a. Apek al-qur'an dan Hadis, yang membahas hal-hal yang berkaitan dengan al-qur'an dan Hadis.

b. Aspek keimanan dan akidah, yang membahas berbagai konsep keimanan yang meliputi enam rukun iman.

33 Muhammad Kosim, Pemikiran Pendidikan Islam Ibnu Khaldun (Jakarta: Rineka Cipta, 2012), hlm. 142-143. 
c. Aspek akhlak, yang membahas berbagai sifat terpuji (akhlakul karimah) yang harus diikuti, dan sifat-sifat tercela yang harus dijauhi.

d. Aspek hukum Islam atau syariah Islam, yang membahas berbagai konsep keagamaan yang terkait dengan masalah ibadah dan muamalah.

e. Aspek tarikh Islam, yang membahas sejarah perkembangan (peradaban Islam) yang bisa diambil manfaatnya untuk diterapkan dimasa sekarang. ${ }^{34}$

Kelima aspek tersebut diatur dalam Peraturan Menteri Pendidikan Nasional (Permendiknas) Nomor 23 Tahun 2006 tentang Standar Kompetensi Lulusan (SKL) untuk Satuan Pendidikan Dasar dan Menengah, termasuk di dalamnya Madrasah Ibtidaiyah (MI) sebagai pendidikan dasar, serta Madrasah Tsanawiyah (MTs) dan Madrasah Aliyah (MA) sebagai pendidikan menengah. Meskipun tekanan kompetensinya berbeda, tetapi masing-masing jenjang tersebut membahas lima aspek, yaitu al-qur'an/hadis, akidah, syariah. Akhlak, dan tarikh Islam.

Namun dalam sekolah umum, seperti SD, SMP, dan SMA materi itu digabungkan ke dalam bidang studi Pendidikan Agama Islam. sementara di madrasah, lima aspek tersebut dikelompokkan lagi menjadi lima bidang studi, yaitu al-qur'an-Hadis, akidah-akhlak, fiqih, sejarah kebudayaan islam, dan bahasa arab. ${ }^{35}$

Adapun ilmu-ilmu umum, juga diklasifikasikan menjadi beberapa bidang studi, baik di lembaga pendidikan agama Islam, maupun lembaga pendidikan umum. Adapun bidang studi yang diajarkan secara garis besar ada empat bidang. Hal ini dapat dilihat dari adanya pengelompokkan mata pelajaran menjadi lima kelompok yang

34 Klasifikasi Materi Pokok PAl dalam Departemen Pendidikan Nasional, Pedoman Khusus Pengembangan Silabus Berbasis Kompetensi SMP Mata Pelajaran Pendidikan Agama Islam (Jakarta: Dirjen Pendidikan Dasar dan Menengah, 2004,), hlm. 18.

35 Muhaimin, Arah Baru pengembangan Pendidikan Islam, Pemberdayaan, Pengembangan Kurikulum Hingga Redefinisi Islamisasi Pengatahuan (Bandung: Nuansa, 2003), hlm. 187. 
ditetapkan dalam Permendiknas No. 23 Tahun 2006 tentang SKL. Di sana disebutkan bahwa Standar Kompetensi Kelompok Mata pelajaran (SKKMP) terdiri atas kelompok-kelompok mata pelajaran sebagai berikut:
a. Agama dan akhlak mulia
b. Kewarganegaraan dan kepribadian
c. Ilmu pengetahuan dan teknologi
d. Estetika
e. Jasmani, olahraga, dan kesehatan.

Dengan semikian, secara teoritis ada sedikit relevansi antara kurikulum yang digagas oleh Ibnu Khldun dengan kurikulum yang dikembangkan dalam pendidikan Islam di Indonesia, yaitu bidang klasifikasinya. Namun bidang mata pelajaran yang dikembangkan terdapat perbedaan yang mendasar. Tampaknya Ibnu Khaldun menghendaki agar pendidikan Islam memperkenalkan kedua kelompok ilmu tersebut secara seimbang. Berbeda di Indonesia, pengklasifikasian ini justru menimbulkan dilema baru, dimana umat Islam terjebak pada sistem pendidikan yang dikotomis.

Menyikapi persoalan ini, perlu dilakukan beberapa upaya untuk mengintegrasikan kedua kelompok ilmu tersebut. Beberapa upaya tersebut mulai dirintis oleh pemegang kebijakan dan tokoh pendidikan Islam di Indonesia. Salah satu diantaranya ialah dengan melakukan konversi IAIN atau STAIN menjadi UIN. Dalam hal ini Abudin Nata menyebutkan bahwa dikotomi ilmu dapat diatasi dengan program integrasi antara ilmu-ilmu agama dan ilmu-ilmu umum, dengan cara mengubah IAIN menjadi UIN.

Menurutnya, IAIN hanya menyelenggarakan program studi agama saja. Hal ini dinilai hanya melestarikan dikotomi tersebut. untuk itu, upaya konversi ini telah mulai dirintis oleh beberapa PTAI seperti UIN Malang yang sebelumnya STAIN, kemudian IAIN menjadi UIN, diantaranya UIN Syarif Hidayatullah, UIN Sunan Kalijaga Yogyakarta, UIN Sultan Syarif Kasim Pekanbaru dan lain sebagainya. ${ }^{36}$

4. Relevansi metode pendidikan

${ }^{36}$ Muhammad Kosim, Op. Cit., hlm. 134-136. 
Dari beberapa metode yang dikemukakan oleh Ibnu Khaldun, diantaranya ada yang relevan dengan pelaksanaan pendidikan Islam yang telah ada di Indonesia. Metode hafalan masih digunakan masih menghapal mufradat bahasa Arab, qawaid, dan ayat-ayat al-qur'an. Dialog biasanya digunakan ketika adanya muzakaroh atau dalam membahas setiap ilmu yang sifatnya membutuhkan diskusi. Widya wisata juga dilakukan oleh peserta didik, terutama kaum santri yang mondok dipesantren selama beberapa tahun.

Begitu juga dengan metode keteladanan, biasanya tampak jelas dipesantren, dimana para kiayi menjadi figur cebtral bagi santrisantrinya. Namun metode yang terakhir ini perlu ditingkatkan dalam konteks kekinian di Indonesia. Tampaknya telah terjadi pergeseran yang jelas antara guru dan murid. Agaknya fenomena ini terjadi akibat dari ketidakmampuan guru menjadi teladan bagi murid-muridnya. Guru hanya tampil sebagai fasilitator sehingga peranannya sebagai instrumen bagi anak didiknya. Semestinya, guru menggunakan keteladanan sehingga kepribadian peserta didik dengan mudah tampak terbentuk. ${ }^{37}$

Persoalan metode tampaknya terus menjadi bahan diskusi yang tetap aktual. Sebab, metode sangat menentukan berhasil tidaknya proses pendidikan yang dilaksanakan dalam mencapai tujuan pendidikan. Untuk itu metode mesti dikembangkan secara dinamis sesuai dengan kebutuhan dan tuntutan zaman.

Pelaksanaan pendidikan Islam di Indonesia selama ini masih butuh pembenahan dan pengembangan metode mengajar. Apa-apa yang pernah dikritik oleh Ibnu Khaldun, seperti menggunakan metode hafalan pada bidang yang tepat. Demikian juga prinsip-prinsip yang ditawarkan oleh Ibnu Khaldun, jika dibandingkan dengan apa yang diharapkan tidak jauh berbeda. Ini menunjukkan bahwa konsep yang diberikan oleh Ibnu Khaldun belum terlaksana dengan sepenuhnya. Itu

37 Ibid., hlm. 138-139. 
artinya pemikiran Ibnu Khaldun tetap relevan dengan kebutuhan saat ini. ${ }^{38}$

\section{Penutup}

Dari uraian di atas dapat kita simpulkan bahwa Nama lengkapnya Abdurrahman bin Muhammad bin Muhammad bin Muhammad bin Hasan bin Jabir bin Muhammad bin Ibrahim bin Abdurrahman bin Ibn Khaldun. Lahir di Tunisia pada 1 Ramadhan 732 H/ 27 Mei 1332. la meninggal pada tahun 1406 dalam usia 74 tahun, bersama jabatan yang dipegangnya. Adapun pemikiran Ibnu Khaldun yang memiliki relevansi terhadapa pelaksanaan pendidikan Islam di Indonesia adalah:

1. Tujuan pedidikan Islam

Relevansi konsep Ibnu Khaldun mengenai tujuan pendidikan Islam dengan pelaksanaan di Indonesia tampaknya masih bersifat teoritis. Sebab dalam pelaksanaan pendidikan Islam di Indonesia manusia masih dipandang secara parsial. Akibatnya, tujuan pendidikan yang telah dirumuskan terhambat dalam pencapaiannya.

2. Meskipun Ibnu Khaldun tidak khusus berbicara tentang pendidik dengan peserta didik, tetapi konsep yang beliau tawarkan tetap relevan untuk dikaji dan dikembangkan dalam meningkatkan pendidikan Islam di Indonesia. Sesuai dengan amanah UU No. 14. Tahun 2005 tentang guru dan dosen, guru dituntut agar memiliki kompetensi profesional, paedagogis, individual dan sosial. Pandangan Ibnu Khaldun tampaknya mampu mengarahkan guru untuk mencapai keempat kompetensi tersebut. Sedangkan, Pandangan mengenai peserta didik bahwa peserta didik tidak hanya dituntut cerdas secara intelektual semata, tetapi mesti cerdas secara emosional, spritual, dan terpenting lagi cerdas secara religious sehingga jadilah ia sebagai anak yang saleh. Inilah profil peserta didik yang ideal dan senantiasa diharapkan sebagaimana yang terkandung dalam tujuan pendidikan nasional.

3. Klasifikasi ilmu sebagaimana yang telah dirumuskan oleh Ibnu Khaldun juga terjadi dalam pendidikan Islam di Indonesia. Jika Ibnu Khaldun

38 Ibid. 
membagi ilmu secara garis besar kedalam dua bentuk, al-ulum alnaqliyah dan al-ulum al-aqliyah, maka di Indonesia juga dibagi dalam dua bentuk, yaitu ilmu agama dan ilmu umum. Kedua bentuk ilmu ini menjadi bagian dalam kurikulum pendidikan Islam di Indonesia.

4. Dari beberapa metode yang dikemukakan oleh Ibnu Khaldun, diantaranya ada yang relevan dengan pelaksanaan pendidikan Islam yang telah ada di Indonesia. Metode hafalan masih digunakan masih menghapal mufradat bahasa Arab, qawaid, dan ayat-ayat al-qur'an. Dialog biasanya digunakan ketika adanya muzakaroh atau dalam membahas setiap ilmu yang sifatnya membutuhkan diskusi. Widya wisata juga dilakukan oleh peserta didik, terutama kaum santri yang mondok dipesantren selama beberapa tahun.

\section{Daftar Pustaka}

A.Susanto, Pemikiran Pendidikan Islam, Jakarta: Amzah, 2010.

Al-Rasyidin dan Samsul Nijar, Filsafat Pendidikan Islam, Jakarta: Ciputat Press, 2005.

Al-Rasyidin dan Wahyuddin Nur Nasution, Teori Belajar dan Pembelajaran, Medan: Perdana Publishing, 2011.

Abuddin Nata, Filsafat Penididkan Islam, Jakarta: Logos Wacana Ilmu, 1997.

Ali Maksum dan Luluk Yunan Ruhendi, Paradigma Pendidikan Universal di Era Modern dan Post-Modern Yogyakarta:IRCiSoD, 2003.

Dewan Redaksi Ensiklopedi Islam, Ensiklopedi Islam, Jakarta: Ichtiar Van Hoeve, 1994.

Fakhur Ray Dalimunthe, Filsafat Pendidikan Islam, Medan: IAIN Perss, 2002.

Haris Hermawan, Filsafat Pendidikan Islam, Jakarta: Direktorat Jenderal Pendidikan Islam Depertemen Agama Republik Indonesia, 2009. 
Maisaroh

Huseiyn Ahmad Amin, Seratus Tokoh Dalah Sejarah Islam, Bandung: Maktabah Madbuli, Kairo, Mesir. 2003.

Jamil Ahma, Seratus Muslim Terkemuka, Jakarta: Pustaka firdaus, 1993.

Klasifikasi Materi Pokok PAI dalam Departemen Pendidikan Nasional, Pedoman Khusus Pengembangan Silabus Berbasis Kompetensi SMP Mata Pelajaran Pendidikan Agama Islam, Jakarta: Dirjen Pendidikan Dasar dan Menengah, 2004.

Muhammad Kosim, Pemikiran Pendidikan Islam Ibnu Khaldun, Jakarta: Rineka Cipta, 2012.

Muhaimin, Arah Baru pengembangan Pendidikan Islam, Pemberdayaan, Pengembangan Kurikulum Hingga Redefinisi Islamisasi Pengatahuan, Bandung: Nuansa, 2003.

Ramayulis, Ensiklopedi Tokoh pendidikan Islam, Jakara: Quantum Teaching, 2005.

RA Gunadi, Dari Penekluk Jerussalem Hingga Angka Nol, Jakarta: Republika, 2002.

Syamsul Kurniawan dan Erwin Mahrus, Jejak Pemikiran Tokoh Pendidikan Islam, Jakarta: Ar-Ruzz Media, 2011.

Warul Walidin, Konstelasi Pemikiran Pedagogik Ibnu Khaldun Perspektif Pendidikan Modern, Yogyakarta:Nadia Foundation, 2003.

Waru Walidin, Katalog Dalam Terbitan (KDT) Konstelasi Pemikiran Pedagogik Ibnu Khaldun (Yogyakarta: Nadiya Foundation, 2003. 